\title{
GROWTH AND REPRODUCTION OF BOOPS BOOPS, DENTEX MACROPHTHALMUS, DIPLODUS VULGARIS, AND PAGELLUS ACARNE (ACTINOPTERYGII: PERCIFORMES: SPARIDAE) FROM EAST-CENTRAL AEGEAN SEA, TURKEY
}

\author{
Ozan SOYKAN*, Akın Türker İLKYAZ, Gülnur METİN, and Hasan Tuncay KINACIGİL \\ Ege University Faculty of Fisheries, Bornova, Izmir, Turkey
}

\begin{abstract}
Soykan O., İlkyaz A.T., Metin G., Kınacigil H.T. 2015. Growth and reproduction of Boops boops, Dentex macrophthalmus, Diplodus vulgaris, and Pagellus acarne (Actinopterygii: Perciformes: Sparidae) from east-central Aegean Sea, Turkey. Acta Ichthyol. Piscat. 45 (1): 39-55.
\end{abstract}

\begin{abstract}
Background. The bogue, Boops boops (Linnaeus, 1758); large-eye dentex, Dentex macrophthalmus (Bloch, 1791); common two-banded seabream, Diplodus vulgaris (Geoffroy Saint-Hilaire, 1817); and axillary seabream, Pagellus acarne (Risso, 1827) are four commercially important sparid species which are distributed in the Mediterranean. Although they are very common in the Mediterranean, information regarding; growth, length at first maturity, and age are scarce and variable. This study provides some of the first data on the above-mentioned biological parameters of these four sparid species for the Turkish coasts of the Aegean Sea (Mediterranean). The aim of the present study is to expand our knowledge on the biology of these commercial sparid species from the Aegean Sea.

Materials and methods. Fish samples were collected between July 2004 and June 2007 by R/V Egesüf from İzmir Bay. Demersal trawl samplings were carried out by a traditional trawl net with a $5 \mathrm{~m}$ codend $(600 \mathrm{mesh}$ circumference at the codend) and made of knotted polyethylene material with $40 \mathrm{~mm}$ mesh size netting.

Results. The length-weight relations determined in the course of this study were: $W=0.005 L^{3.25}$ (bogue), $W=0.005 L^{3.03}$ (large-eye dentex), $W=0.007 L^{3.31}$ (common two-banded seabream), and $W=0.009 L^{3.14}$ (axillary seabream). The respective $L_{¥}$ and $k$ parameters of von Bertalanffy growth equation were: 29.58 and 0.266 for bogue; 24.3 and 0.399 for large-eye dentex; 28.0 and 0.253 for common two-banded seabream; and 22.7 and 0.315 for axillary seabream. Furthermore, lengths at first maturity were determined as: 12.96 ( + ) and 9.35 (ठ)

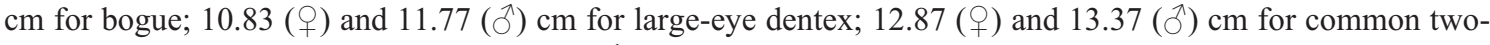
banded seabream; and $14.45(+)$ and $13.91\left({ }^{\Uparrow}\right) \mathrm{cm}$ for axillary seabream.

Conclusion. The presently determined parameters of age, growth, reproduction, and mortality of these four species will be useful for estimating the relevant parameters of population dynamics and will hopefully contribute to a better understanding of the long-term changes of the stock sizes.
\end{abstract}

Keywords: bogue, large-eye dentex, common two-banded seabream, axillary seabream, age, maturity

\section{INTRODUCTION}

Fishes of the family Sparidae are widespread in the Mediterranean and constitute an important fishery resource along its coasts (Gordoa and Molí 1997). They can inhabit a wide range of marine habitats, from rocky to sand bottoms at depths from 0 to $500 \mathrm{~m}$, although they are usually more common at less than $150 \mathrm{~m}$ deep (Abecasis et al. 2008). For the presently reported study, four sparid fishes which are very common in the Mediterranean were selected: bogue, Boops boops (Linnaeus, 1758); large-eye dentex, Dentex macrophthalmus (Bloch, 1791); common two-banded seabream, Diplodus vulgaris (Geoffroy SaintHilaire, 1817); and axillary seabream, Pagellus acarne
(Risso, 1827). Bogue inhabit shelf or coastal pelagic areas on various bottoms (sand, mud, rocks, and seaweeds); and large-eye dentex and common two-banded seabream both inhabit rocky or sandy bottoms; while the habitat of axillary seabream varies but they are most often found on sea grass beds and sand (Froese and Pauly 2014). These species are of commercial importance along the Mediterranean coasts and together they comprise almost 1\% of Turkish fish capture production (Anonymous 2012).

Although many studies have focused on different aspects of their biology (Gordoa and Molí 1997, Abecasis et al. 2008, Pajuelo and Lorenzo 2000, Gonçalves et al. 2003, Kilongo et al. 2007, Fehri-Bedoui et al. 2009), information

\footnotetext{
${ }^{*}$ Correspondence: Dr. Ozan SOYKAN, Ege Üniversitesi Su Ürünleri Fakültesi, Avlama-İşleme Teknolojisi Bölümü, Avlama Teknolojisi Anabilim Dalı, 35100, Bornova, İzmir, Turkey, phone: +90 232-311-4098, fax: +90 232-374-5050, e-mail: (OS) ozansoykan@hotmail.com, (ATi) ilkyaza@gmail.com, (GM) gulnur.metin@ege.edu.tr, (HTK) h.tuncay.kinacigil@ege.edu.tr.
} 
regarding the growth, length at reproduction and age are scarce and variable. The goal of the presently reported study was to determine parameters of growth, length at first maturity, and age of the earlier-mentioned four sparid species from Turkish coasts of the Aegean Sea (Mediterranean).

\section{MATERIALS AND METHODS}

Fish samples were collected from İzmir Bay (Fig. 1) between July 2004 and June 2007 by R/V Egesüf, owned by the Ege University. The study area comprised three subareas. Subarea 1 is open for all commercial fishing activities. Subarea 2 is open only for small-scale fisheries (gillnets and longlines etc.) but closed for trawlers and purse seiners. Subarea 3-a military zone-is open only for scientific studies but prohibited for all fishing activities including recreational fishing. Demersal trawl samplings were carried out by a traditional trawl net with a $5 \mathrm{~m}$ codend (600 mesh circumference at the codend) and made of knotted polyethylene material with $40 \mathrm{~mm}$ mesh size netting with a codend liner of $8 \mathrm{~m}$ length made of knotless polyamide material with $22 \mathrm{~mm}$ mesh size netting in order to capture smaller individuals (Tosunoğlu et al. 1996). Hauling time was determined as the time between the end of steel rope release and the start of haul back. Each of the

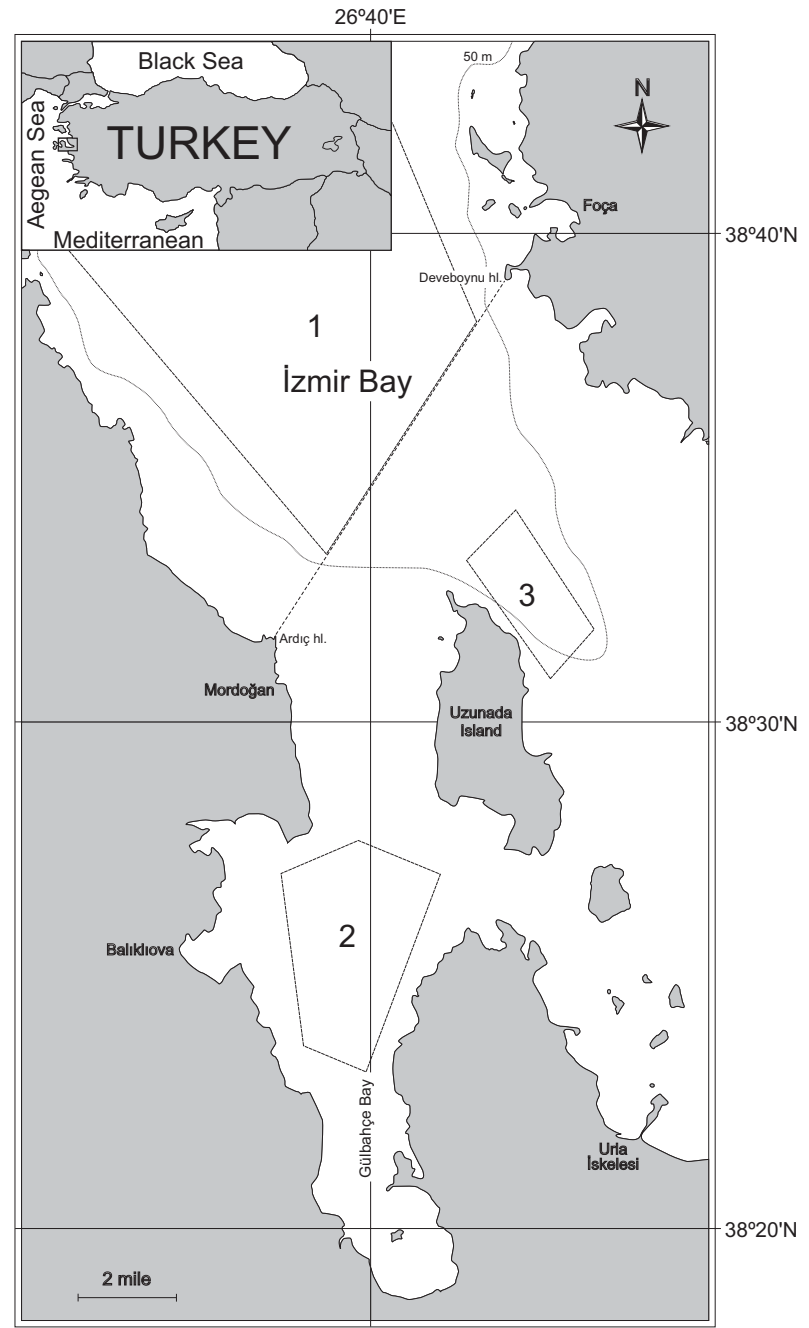

Fig. 1. The study area: İzmir Bay east-central Agean-Sea operations took $1 \mathrm{~h}$ and hauling speed was $4.0-4.4 \mathrm{~km} \cdot \mathrm{h}^{-1}$ (2.2 to 2.4 knots).

Total length (TL) was measured in the natural body position to the nearest $1 \mathrm{~mm}$. Total weight $(W)$ and gonad weight $\left(W_{\mathrm{g}}\right)$ were determined to the nearest $0.01 \mathrm{~g}$, and the sex was recorded. The mean length and weight values were given with standard errors. Pooled data were used to draw annual length frequency diagrams. Sagittal otolith pairs were removed for each length group, cleaned, and stored under dry conditions inside microplates (smaller ones) and Eppendorf tubes ${ }^{\circledR}$ (bigger ones) to determine the age of the specimens.

The sex and gonad maturity stages were determined by macroscopic observation of the gonads. Individuals having only male gonad were determined to be male, likewise only female gonad carrying individuals were determined to be female. Specimen having both male and female gonads regardless of the weight and volume of the gonads were treated as hermaphrodites. Maturity stages were determined according to Gunderson (1993) who distinguished 5 stages: stage I (immature), stage II (resting), stage III (developing), stage IV (ripe), and stage V (spent). The female to male $(\mathrm{F}: \mathrm{M})$ ratio was calculated and chi-square $\left(\chi^{2}\right)$ test was applied for determining the significance of the male to female ratio.

The length-weight relation was calculated with the formula

$$
W=a L^{b}
$$

where $W$ refers to total body weight [g], $L$ is total length [cm], and $a$ and $b$ are coefficients (Ricker 1973). The parameters $a$ and $b$ (intercept and slope, respectively) of the length-weight relation were estimated according to linear regression analysis of log-transformed data. The degree of association between variables was calculated by the determination coefficient $\left(R^{2}\right)$.

Only individuals captured from the subarea 1 were used for age estimations. Data for age estimations obtained from entirely or partially prohibited areas (subarea 2 and 3 ) were excluded because the age data was also used to calculate the fishing mortality $(F)$, total mortality $(Z)$, and the exploitation ratios $(E)$. Age estimations were carried out on sagittal otoliths and made by two experienced independent readers who never had prior access to any information of the individual (size, sex, or date of capture etc.) while they were counting growth increments. The data set which was agreed to by the independent readers was used for the estimations. If the readings did not coincide, the otolith was rejected and not considered in subsequent analyses. The otoliths of 182 bogue, 265 large-eye dentex, 206 common two-banded seabream, and 235 axillary seabream were used for age determination. Cross sections of some otoliths - which were hard to observe because of calcium accumulation on the surface of the otolith-were made and determination was performed on these sections using a stereoscopic zoom microscope with otoliths viewed under reflected light against a black background. Opaque and transparent rings were counted: 1 opaque zone together with 1 transparent zone was considered to be the annual growth indicator. 
Standard non-linear optimization methods (Sparre and Venema 1998) were used for estimating the growth and von Bertalanffy growth function was applied to size-atage data. The function

$$
L_{t}=L_{\infty}\left[1-\mathrm{e}^{-k(t-t o)}\right]
$$

was fitted to the data, where $L_{t}$ is the fish length [cm] at time $t$ [year], $L_{\infty}$ is the asymptotic length [cm], $k$ is the growth coefficient [year ${ }^{-1}$ ], and $t_{0}$ [year] is the hypothetical time at which the length is equal to zero. In addition, accuracy of the growth parameters was examined using Munro's growth performance index

$$
\varphi^{\prime}=\log (k)+2 \log \left(L_{\infty}\right)
$$

and the $t$-test (Pauly and Munro 1984).

The spawning period was determined according to monthly variation of the gonadosomatic index (GSI) [\%] using the equation

$$
\mathrm{GSI}=100 W_{\mathrm{g}} \cdot\left(W-W_{\mathrm{g}}\right)^{-1}
$$

where $W_{\mathrm{g}}$ is the gonad weight $[\mathrm{g}]$ and $W$ is the total weight [g] of the fish (Ricker 1975). Length at first maturity $\left(L_{m}\right)$ was defined as the length at which $50 \%$ of the population investigated was near spawning (King 1996). The length at $50 \%$ maturity was determined with the L50 computer program LogLog function (İlkyaz et al. 1998). The equations

and

$$
r(l)=\exp (-\exp (-(a+b l)))
$$

$$
L_{m}=(-\ln (-\ln (0.5))-a) \cdot b^{-1}
$$

were applied, where $r(l)$ is the proportion of matures in each length class [\%], $l$ is the fish length [cm], $a$ is the intercept, and $b$ is the slope.

Mortality estimation was calculated by the equation:

$$
Z=F+M
$$

where $Z$ is the total mortality rate, $F$ is the rate of fishing mortality which is caused by the all fishing activity, and $M$ is the rate of natural mortality which includes deaths caused by all other factors (King 1996). The instantaneous rate of total mortality $(Z=-\operatorname{Ln}(S))$ was estimated by fitting the survivors ratio with the formula

$$
S=N_{t+1} \cdot N_{t}^{-1}
$$

where $S$ is the survivor ratio, $N$ is the number of fish belonging to the age group $t$ and $t+1$ (Ricker 1975). The equation

$$
M=\beta \times k
$$

was used to estimate the natural mortality rate, where $\beta$ varied from 1.3 to 2.1 , and $k$ is the growth coefficient (Jensen 1996). $\beta$ was estimated from the equation

$$
\beta=(3-3 \omega) \cdot \omega^{-1}
$$

where $\omega$ is the mean critical length to asymptotic length ratio. Cubillos (2003) calculated $\omega$ parameters for a number of fish families, however he did not include the family Sparidae. He also calculate the mean valued for the families covered by his study, obtaining the value of 0.620 for all species. The fishing mortality rate $(F)$ was calculated from the formula:

$$
F=Z-M
$$

and the exploitation ratio $(E)$ from:

$$
E=F \cdot Z^{-1}
$$

\section{RESULTS}

A total of 421 bogue individuals were sampled during the study, including 82 females, 293 males, and 46 immature fish that were excluded from sex ratio determination. Thus female to male ratio (F : M) of the sample was calculated as $1: 3.57$ and the ratio was statistically significant $\left(\chi^{2}, P<0.05\right)$. The lengths of bogue ranged from 11.0 $\mathrm{cm}$ (sampled in January) to $23.8 \mathrm{~cm}$ TL (sampled in November) (Fig. 2). The mean length and weight of the samples were $15.5 \pm 0.1 \mathrm{~cm}$ and $37.9 \pm 0.8 \mathrm{~g}$, respectively. The length-weight relation was $W=0.005 L^{3.25}\left(R^{2}=\right.$ 0.968 ) for all individuals (Fig. 3), and the result of $t$-test showed that the species' growth type was positive allometry $(P<0.05$; Table 1$)$. High gonadosomatic index (GSI) values were detected from the beginning of December to April, whilst individuals ready for spawning were observed mostly between January and March (Fig. 4). It was also found that the age of bogue ranged from 1 to 5 years. The growth, length, and weight at infinity were calculated as $L_{\infty}=29.58 \mathrm{~cm}$ and $W_{\infty}=302.94 \mathrm{~g}$, respectively. (Table 1, Fig. 5) and the growth performance index was determined as $\varphi^{\prime}=2.37$. Gonad formation occurred at $12.8 \mathrm{~cm}$ in females. However, length at first maturity and age were found as $L_{m}=12.96 \mathrm{~cm}$ and 1 year $(a=-33.362$, $b=2.574, R^{2}=0.778$ ) for females (Fig. 6). Even though the first gonad formation was found at $11.2 \mathrm{~cm}$, length at first maturity for males couldn't be calculated due to insufficient data. Total mortality ratio of the samples was calculated as $Z=1.173 \mathrm{y}^{-1}$, while natural and fishing mortality ratio were $M=0.148 \mathrm{y}^{-1}$ and $F=1.025 \mathrm{y}^{-1}$ respectively. Finally, exploitation ratio $(E)$ of the stock was found as 0.874 .

Large-eye dentex were represented by 716 individuals, including 163 females, 84 males, and 469 juveniles. The female to male ratio of the samples was calculated as $1: 0.52$ and the chi-square analysis showed that this ratio was statistically significant $(P<0.05)$. The lengths of fish ranged from $3.9 \mathrm{~cm}$ (January) to $21.3 \mathrm{~cm}$ TL (October) (Fig. 2). The average length and weight of the specimens were $9.6 \pm 0.1 \mathrm{~cm}$ and $18.8 \pm 0.7 \mathrm{~g}$, respectively. For all individuals, the length-weight relation was $W=0.005 L^{3.03}$ $\left(R^{2}=0.968\right)$ (Fig. 3), with negative allometric growth observed for females and males but positive allometry for all individuals ( $t$-test, $P<0.05$; Table 1$)$. Gonadosomatic index values were found to be high in July and August (Fig. 4). Moreover, individuals ready for spawning reached the maximum number in July. It was also found that age of the stock ranged from 1 to 5 years. The growth, length and weight at infinity were calculated as $L_{\infty}=24.32 \mathrm{~cm}$ and $W_{\infty}=231.00$ g respectively. (Table 1, Fig. 5). The growth performance index was calculated as $\varphi^{\prime}=2.37$. It was determined that formation of gonads occurred at $7.4 \mathrm{~cm}$ in males and $6.7 \mathrm{~cm}$ for females. However, the size of first reproduction length and age were found as $L_{m}=10.83 \mathrm{~cm}$ and 1 year $\left(a=-31.015, b=2.864, R^{2}=0.901\right)$ for females, $L_{m}=11.77 \mathrm{~cm}$ and 1 year $(a=-25.266, b=2.147$, $R^{2}=0.838$ ) were determined for males (Fig. 6). Total mortality ratio of the stock was calculated as $Z=1.598 \cdot \mathrm{y}^{-1}$, while 
natural and fishing mortality ratio were $M=0.734 \cdot \mathrm{y}^{-1}$ and $F=0.863 \cdot \mathrm{y}^{-1}$, respectively. Finally, exploitation ratio $(E)$ of the stock was 0.540 .

A total of 709 common two-banded seabream individuals were studied, including 137 females, 105 males, one hermaphrodite, and 466 immature individuals that were excluded from sex ratio determination. Female to male ratio of the stock was calculated to be $1: 0.77\left(\chi^{2}, P<0.05\right)$. The lengths of fish varied between $7.5 \mathrm{~cm}$ (July) and $19.0 \mathrm{~cm}$ TL (August) (Fig. 2). The mean length and weight of the specimens were $12.4 \pm 0.1 \mathrm{~cm}$ and $31.5 \pm 0.6 \mathrm{~g}$, respectively. The length-weight relation was $W=0.007 L^{3.31}$ $\left(R^{2}=0.970\right)$ for all individuals (Fig. 3 ), with positive allometric growth observed for females, males and all individuals ( $t$-test, $P<0.05$; Table 1 ). Gonadosomatic index

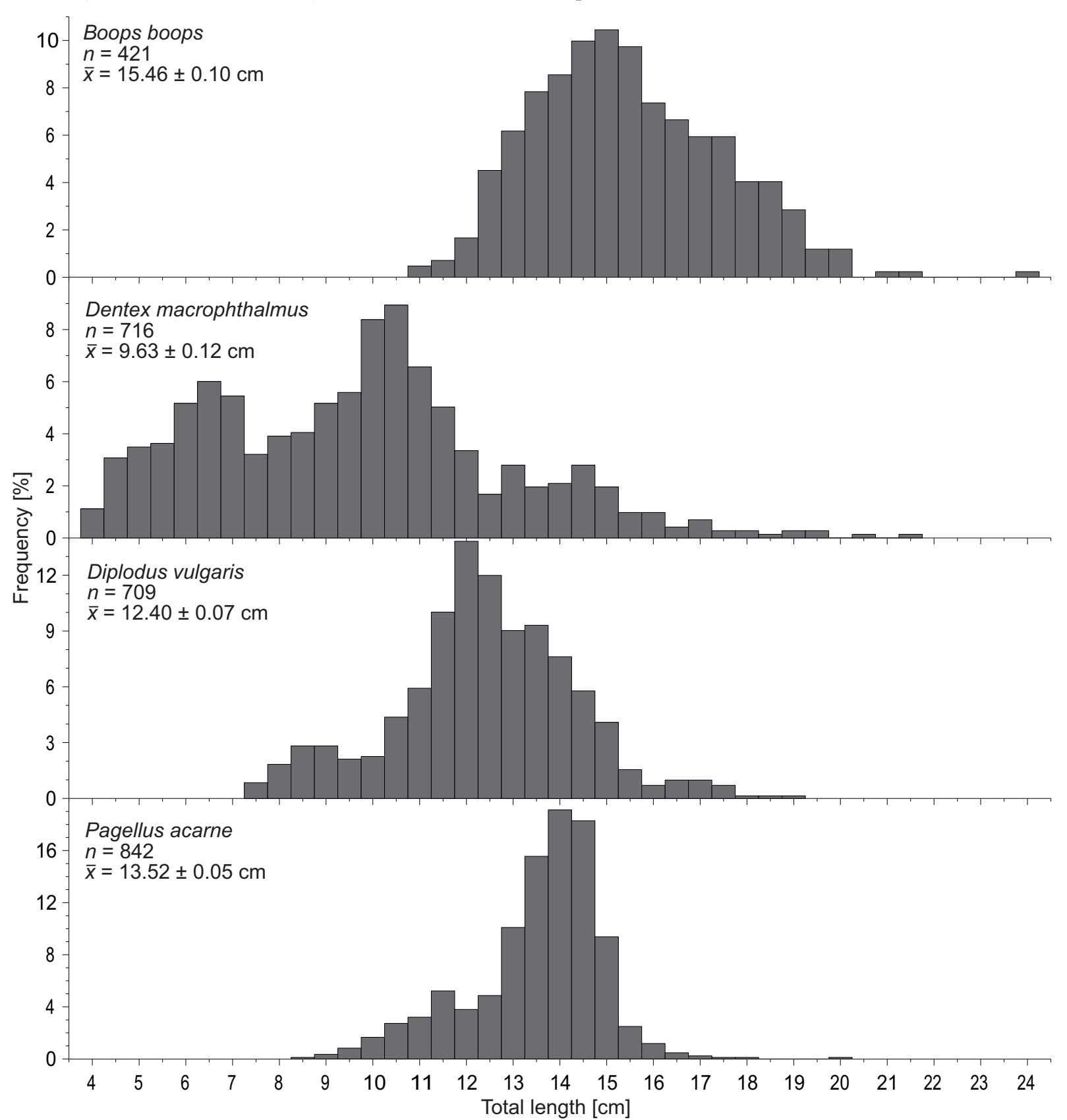

values were highest in December and January when the maximum number of individuals ready for spawning were observed (Fig. 4). It was also determined that age of the stock varied between 1 and 3 years. Length and weight at infinity were calculated as $L_{\infty}=27.96 \mathrm{~cm}$ and $W_{\infty}=425.32$ g, respectively. (Table 1, Fig. 5) and the growth performance index was determined as $\varphi^{\prime}=2.30$. The values of 7.5 and $7.7 \mathrm{~cm}$ were determined to be lengths of gonad formation for males and females, respectively. Moreover, length at first reproduction and age were found as $L_{m}=12.87 \mathrm{~cm}$ and one year $(a=-18.385$, $\left.b=1.429, R^{2}=0.836\right)$ for females, $L_{m}=13.37 \mathrm{~cm}$ and one year $\left(a=-19.257, b=1.440, R^{2}=0.790\right)$ were determined for males (Fig. 6). On the other hand, mortality and exploitation ratio of two-banded seabream couldn't be

Fig. 2. Length-frequency diagram for Boops boops, Dentex macrophthalmus, Diplodus vulgaris, and Pagellus acarne from east-central Aegean Sea, Turkey 
calculated due to insufficient samples obtained in the legal fishing area.

A total of 842 axillary seabream individuals were examined during the study, 281 mature females, 80 mature males, and 481 immature individuals. Female to male ratio was 1: $0.28\left(\chi^{2}, P<0.05\right)$. The lengths of fish ranged from
$8.5 \mathrm{~cm}$ (June) to $20.2 \mathrm{~cm}$ TL (October) (Fig. 2). The mean length and weight of the specimens was $13.5 \pm 0.0 \mathrm{~cm}$ and $31.4 \pm 0.3 \mathrm{~g}$, respectively. The length-weight relation was $W=0.009 L^{3.14}\left(R^{2}=0.972\right)$ for all individuals (Fig. 3), with isometric growth observed for females and males $(t$-test, $P>0.05)$ but positive allometry was detected for
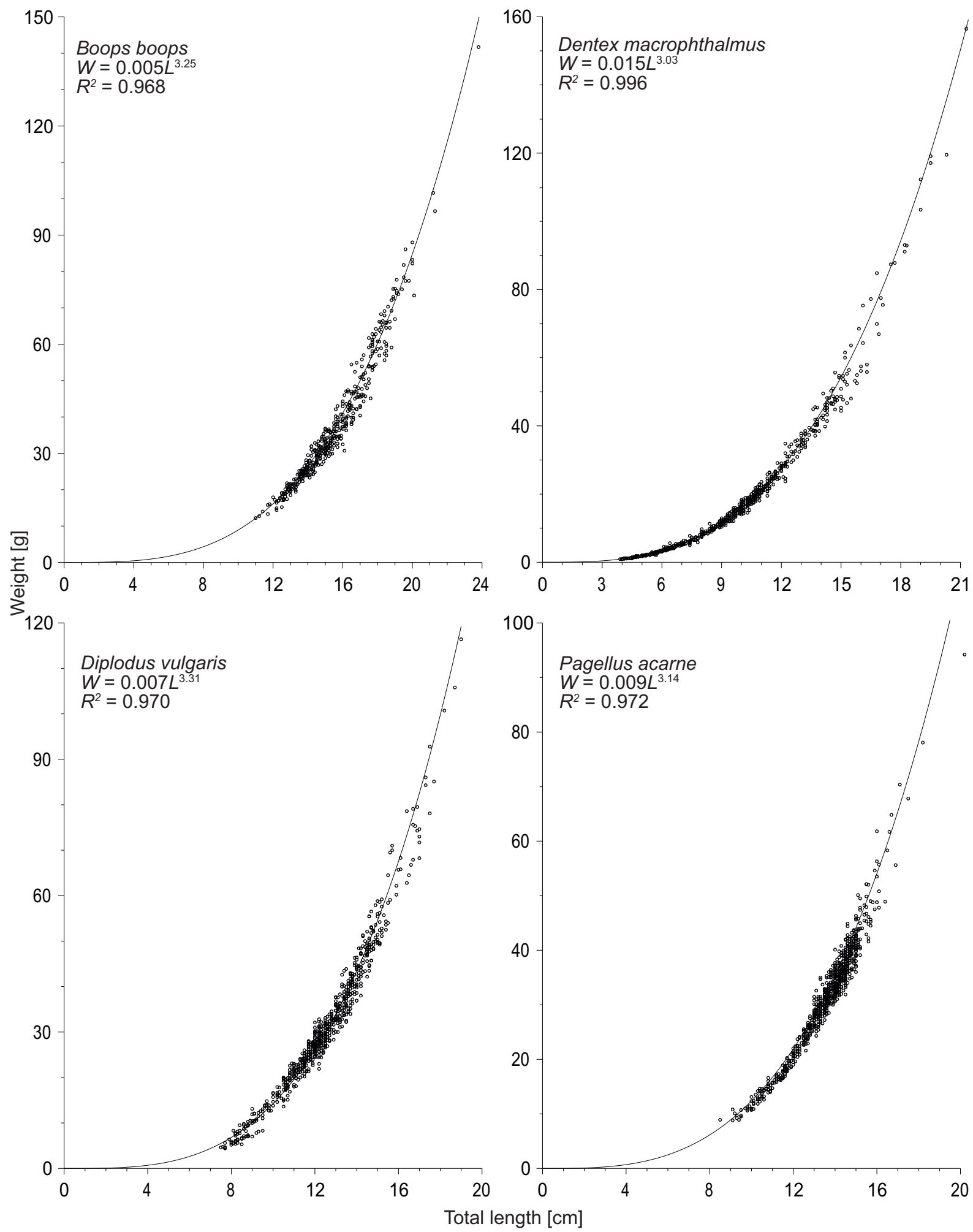

Fig. 3. Length-weight diagram for Boops boops, Dentex macrophthalmus, Diplodus vulgaris, and Pagellus acarne from east-central Aegean Sea, Turkey 
the whole stock ( $t$-test, $P<0.05$; Table 1$)$. High gonadosomatic index values were detected between June and September, while individuals ready for spawning were observed primarily in this period as well (Fig. 4). It was also found that age of the stock ranged from 1 to 6 years. The growth, length and weight at infinity were calculated as $L_{\infty}=22.66 \mathrm{~cm}$ and $W_{\infty}=152.97 \mathrm{~g}$, respectively. (Table 1 , Fig. 5) The growth performance index was calculated as $\varphi^{\prime}=2.21$. It was found that formation of gonads occurred at $12.2 \mathrm{~cm}$ in males and $12.5 \mathrm{~cm}$ for females. However, size at first reproduction and age were found as $L_{m}=14.45 \mathrm{~cm}$ and 2 years $(a=-45.281, b=3.133$, $\left.R^{2}=0.916\right)$ for females, $L_{m}=13.91 \mathrm{~cm}$ and 2 years $\left(a=-55.103, b=3.962, R^{2}=0.918\right)$ were determined for males (Fig. 6). Total mortality ratio of the stock was calculated as $Z=2.395 \cdot \mathrm{y}^{-1}$, while natural and fishing mor- tality ratio were $M=0.579 \cdot \mathrm{y}^{-1}$ and $F=1.816 \cdot \mathrm{y}^{-1}$, respectively. Finally, exploitation ratio $(E)$ of the stock was found as 0.758 .

\section{DISCUSSION}

Axillary seabream was represented with the maximum and bogue with the minimum number of individuals during the study. The low number of bogue samples is attributed to the type of sampling gear as bottom trawls do not generally target this species. It was found that female to male ratios of the three species are in favour of females, while males of bogue dominated their stock. Uneven sex ratios may be explained as a consequence of hermaphroditism which is very common in the fishes of the family Sparidae. Moreover, the length-weight relations of all species, in general, indicated positive allometric growth.
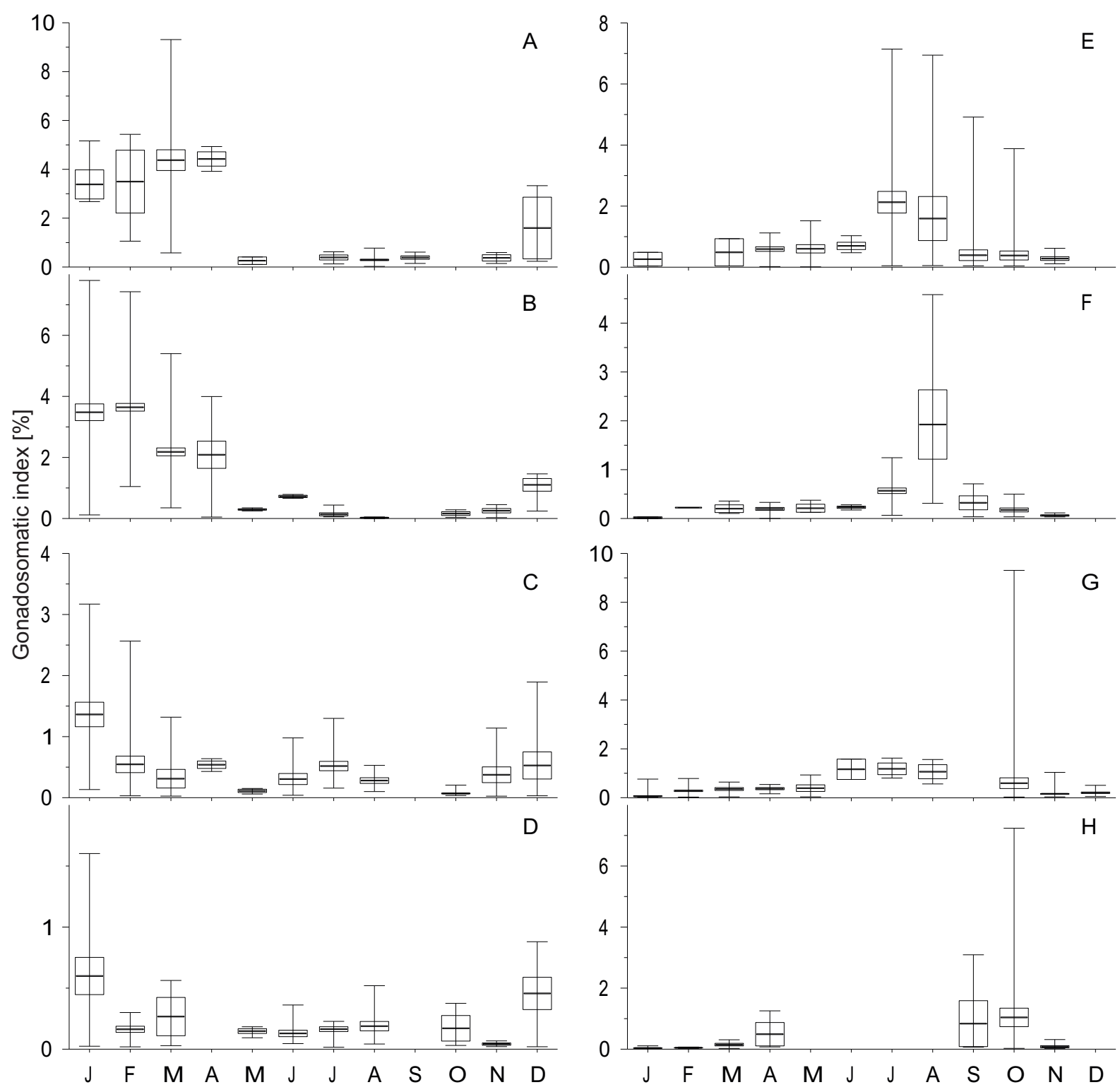

Fig. 4. Monthly average values of gonadosomatic index (GSI) of Boops boops (Aㅇ, B $\overbrace{}^{\Uparrow})$, Diplodus vulgaris $(\mathrm{C} q, \mathrm{D} \overbrace{}^{\Uparrow})$,

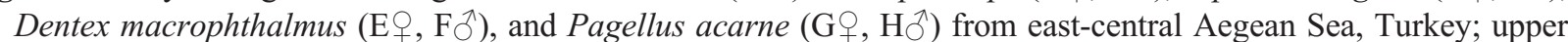
line = maximum; mid line = average; bottom line = minimum value of the GSI; box: standard error of the GSI 


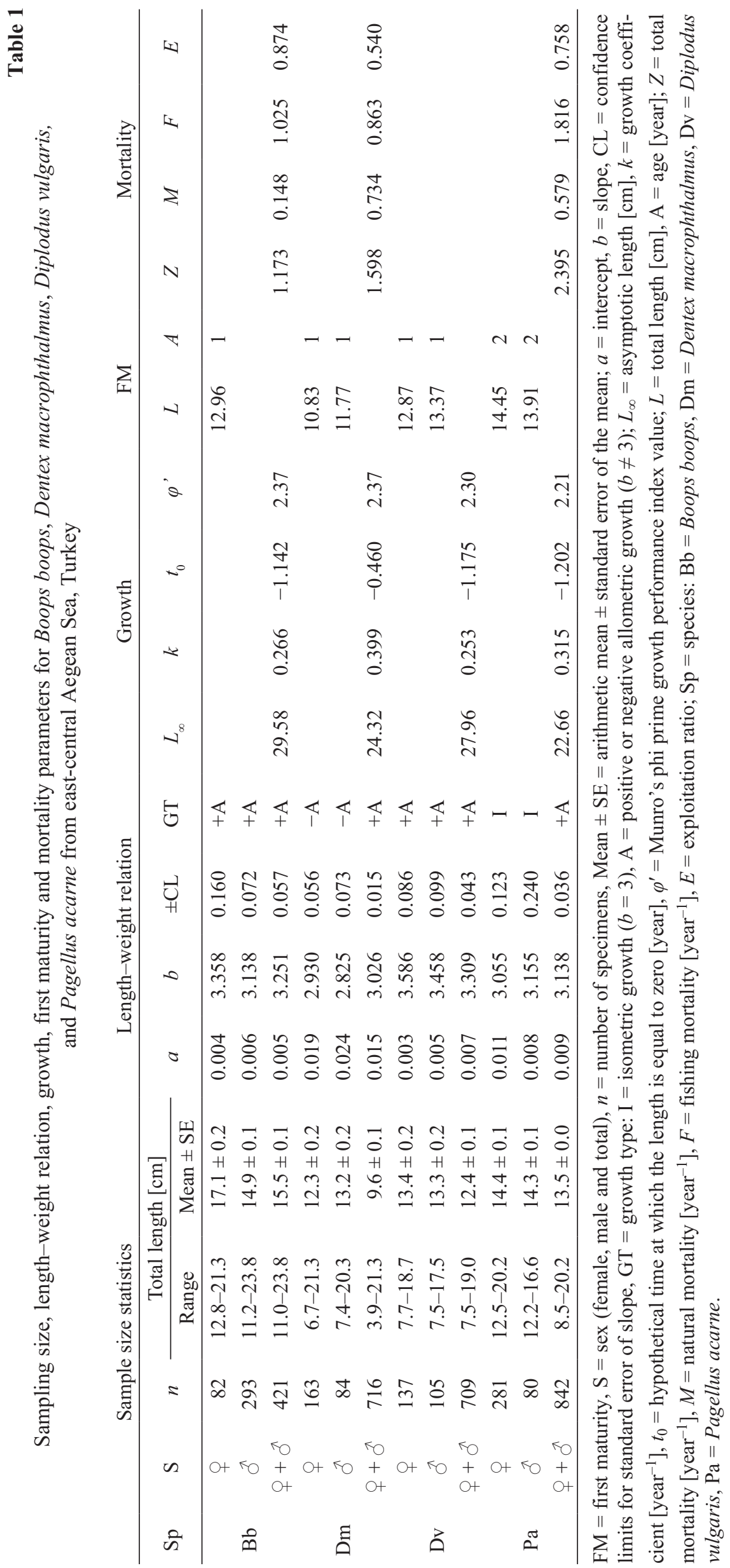


However, male and female individuals of large-eye dentex displayed negative allometry but isometric growth was observed in the males and females of axillary seabream. Results on bogue given by Karakulak et al. (2006) and Özaydın et al. (2007) for north and middle Aegean Sea, respectively, have the highest similarity with our work. On the other hand, some differences have been observed with the length-weight relation parameters of the previous studies including the remaining three species which are believed to come from regional, temporal, and methodological discrepancies (Table 2).

Reproductive seasons of investigated fish varied. It was found that spawning of large-eye dentex and axillary seabream takes place in summer, while bogue spawns in winter and early spring. Monteiro et al. (2006) stated the reproduction season of bogue in Portugal (Algarve) extends from late winter to spring between February and May, which is in accordance with our results. Comparing the reproduction season of this study with those of Pajuelo and Lorenzo (2000), reproduction season of axillary seabream substantially differs in Canary Islands as they reported the reproductive season extended from October to March, with a peak in spawning activity in December-January. The differences could be attributable to geographic discrepancy. In addition, reproductive activity of common two-banded seabream was observed only in winter. The reproduction period of the common two-banded seabream determined in the presently reported study are similar to those reported by Gonçalves et al. (2003) which was given in autumn and winter in Portugal (Algarve). Comparing the reproduction periods of these species in this study with those of Bauchot and Hureau (1986), only large-eye dentex presents different results for the Mediterranean. Those authors reported the reproduction period of the species from March to May for Mediterranean. Potts et al. (2010) stated that females of large-eye dentex with ripe gonads were present throughout most of the year, but the greatest proportion of ripe female fish was found in December and January in Angola. Although the reproduction period varies according to the habitat of the species, no information was found on the reproduction season of large-eye dentex for the Aegean Sea and our findings will be the pioneering results.

Age information is of crucial importance as it creates the basis for growth and mortality estimations (Campana 2001), making it essential for fisheries management (Casselman 1987, Cailliet et al. 2001). Difficulty in reading and interpretation of bogue otoliths and scales was reported by Abecasis et al. (2008). The authors also added that this is in contrast to those of common two-banded and axillary seabream as they show high consistency in otolith observations. It was determined that age of axillary seabream varied from 1 to 6 years, while bogue and large-eye dentex ranged in between 1 and 5 years. Moreover the maximum age for common two-banded seabream was estimated to be 3 years. Age estimations of three sparids; bogue (11 years), common two-banded seabream (14 years), and axillary seabream (18 years) given by Abecasis et al. (2008) are considerably higher than our findings. These differences are attributable to size range and the sampling gear, as the authors used longline, gillnet, and beach seine that enable them to capture greater individuals than the trawling does. Coelho et al. (2005) stated the age range of axillary seabream from 1 to 8 years while Velasco et al. (2011)

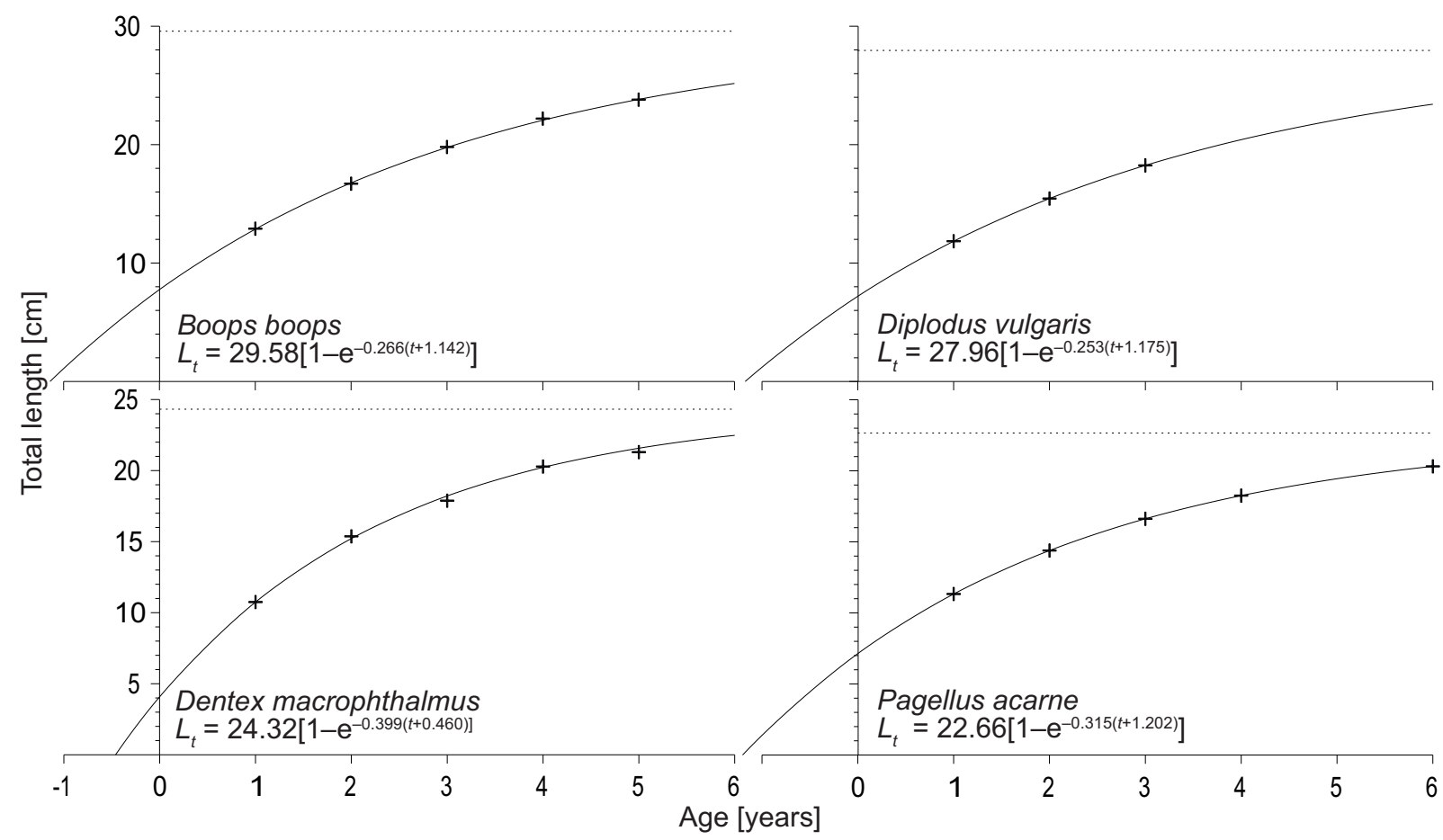

Fig. 5. The von Bertalanffy growth curve for Boops boops, Dentex macrophthalmus, Diplodus vulgaris, and Pagellus acarne from east-central Aegean Sea, Turkey 


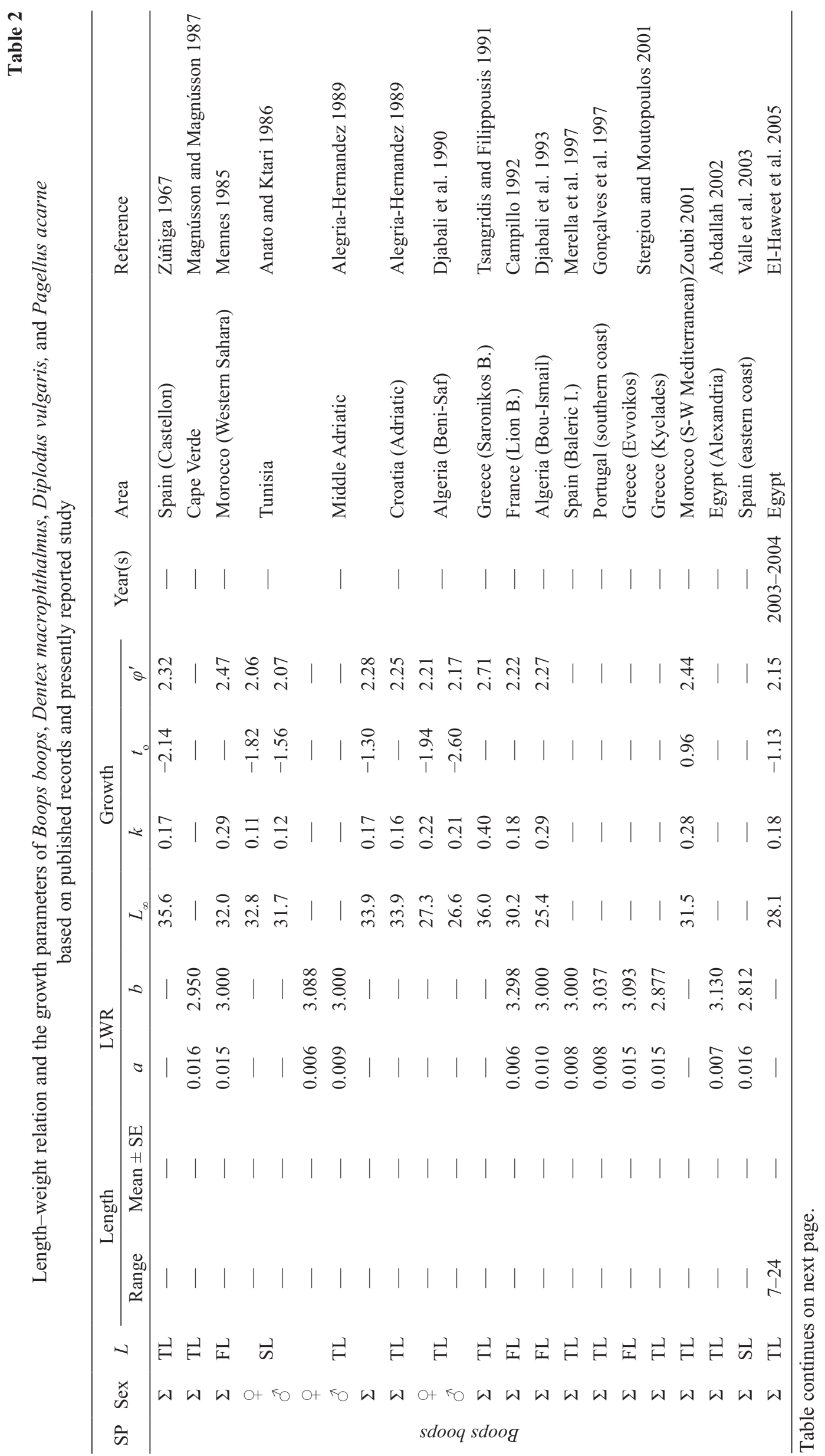




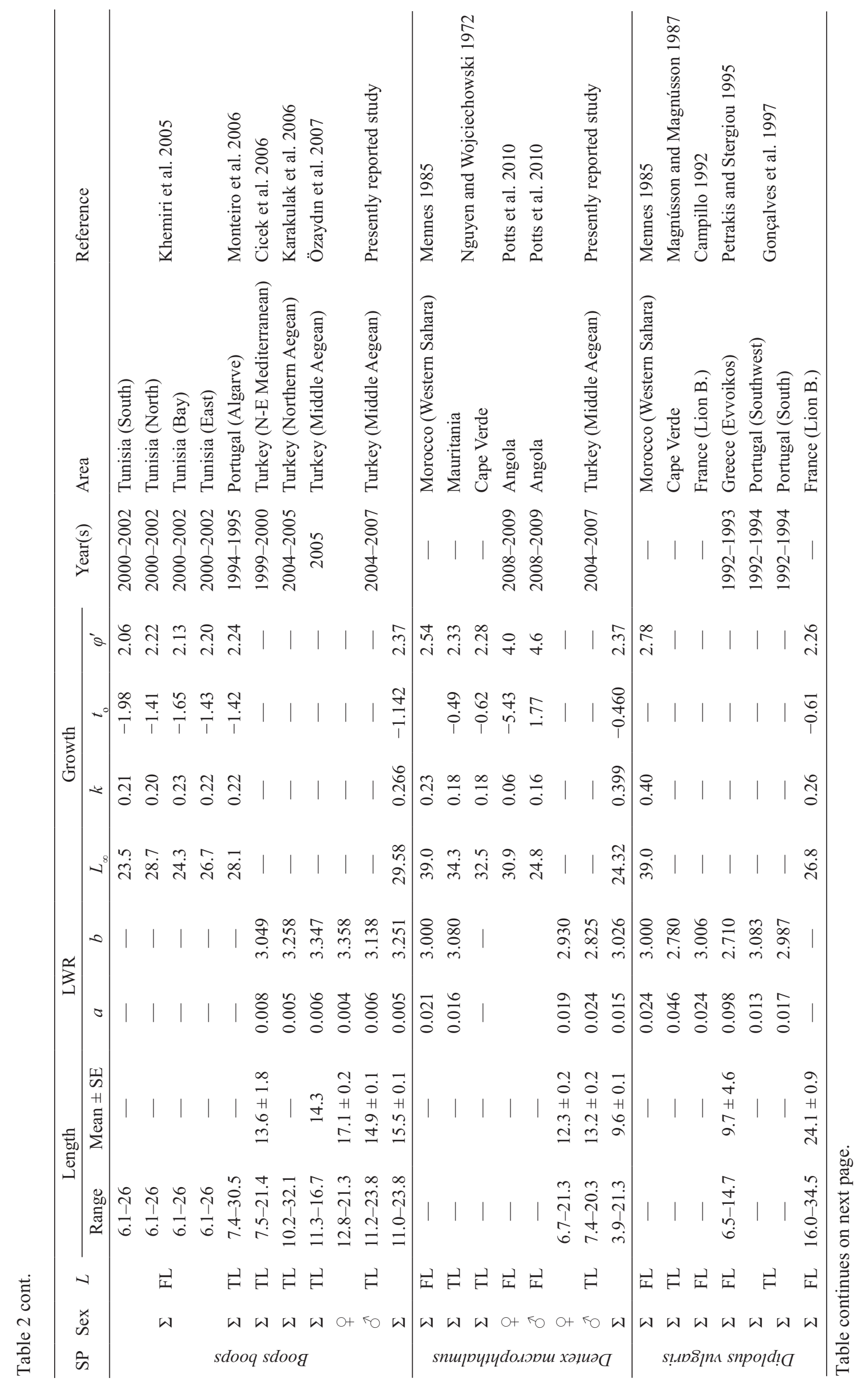




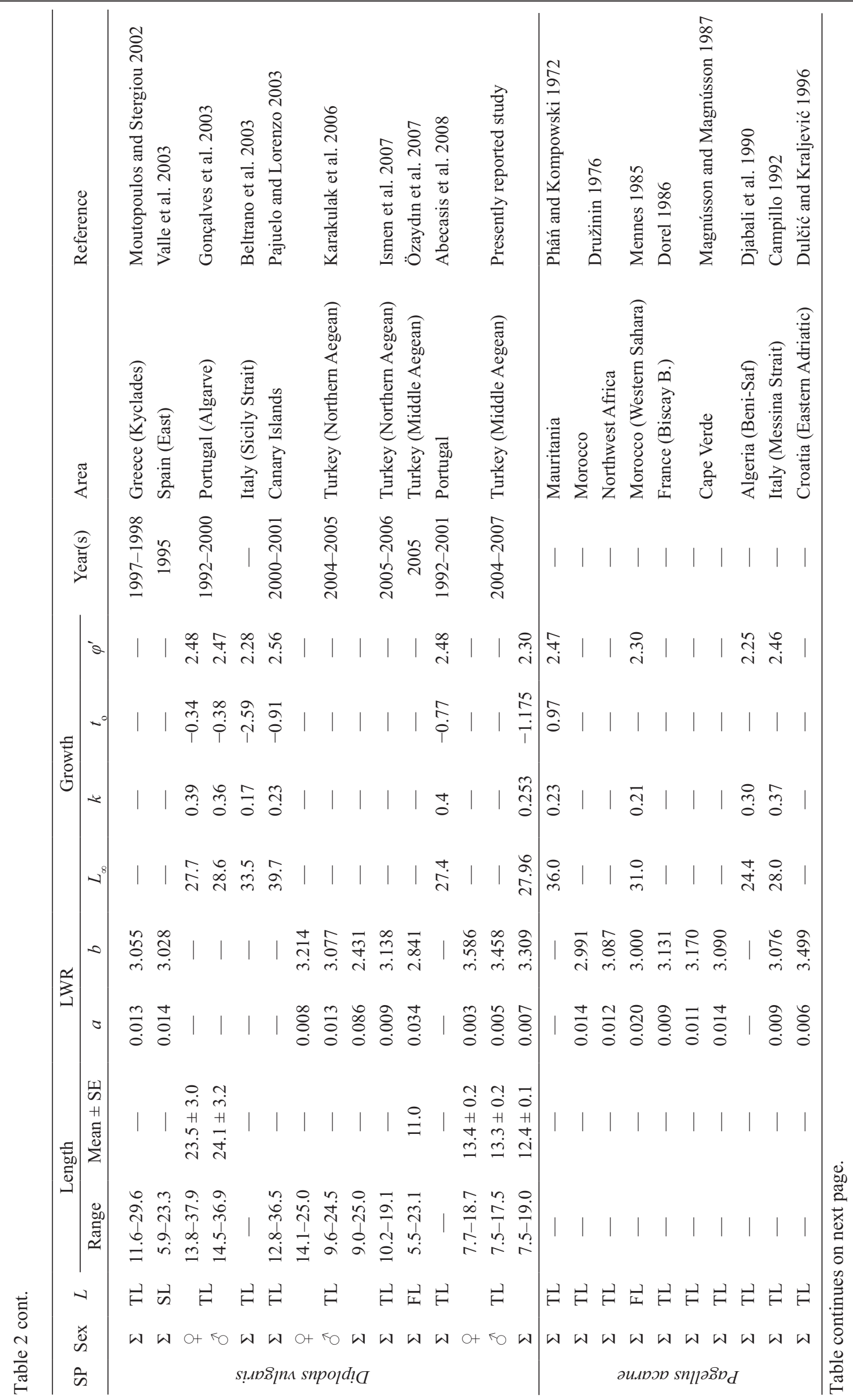




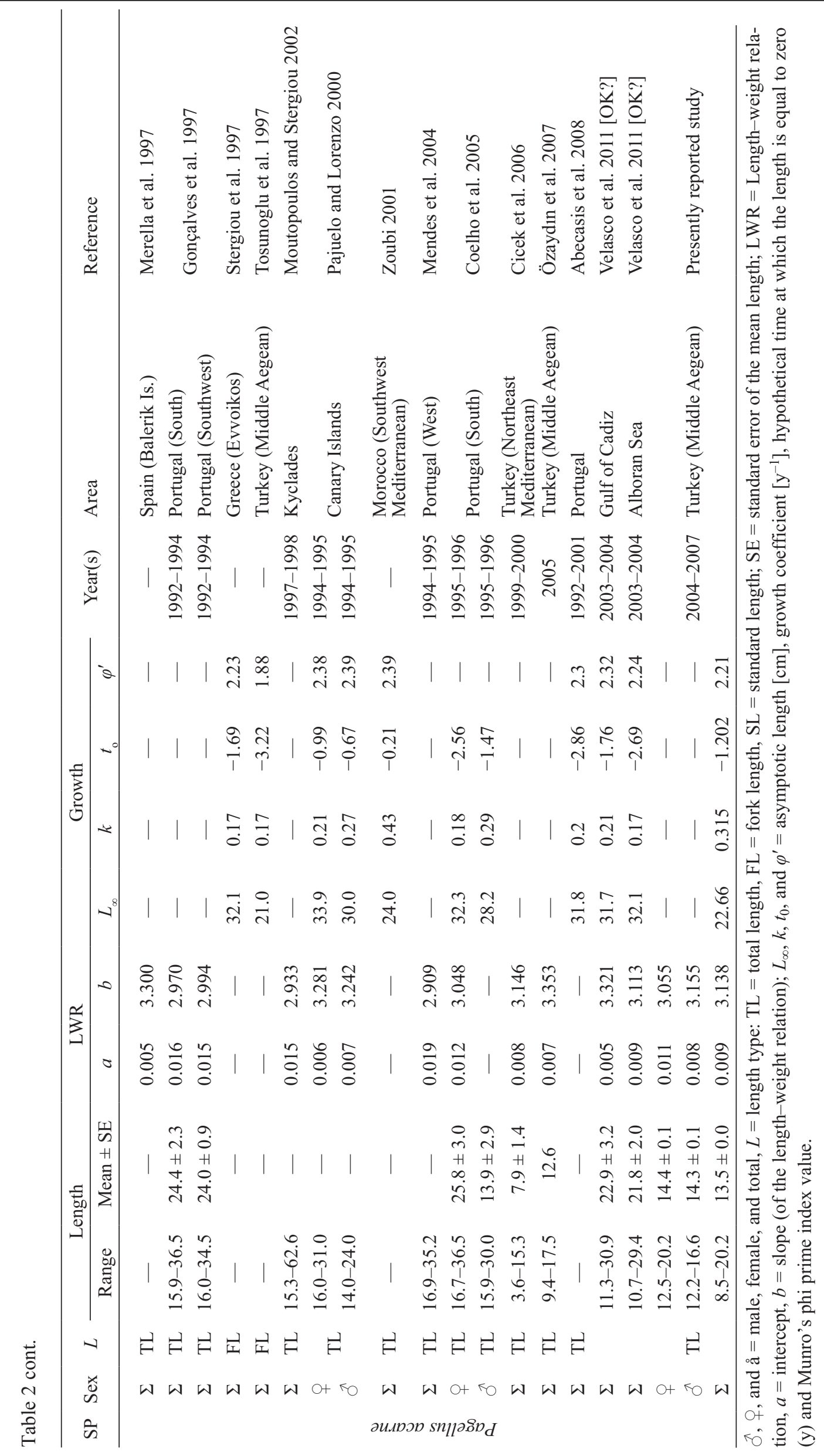


reported individuals between 1 and 7 years. Nevertheless, our results for bogue are similar with those of El-Haweet et al. (2005) as they reported six age groups (1-6 years) while using commercial trawlers. Gordoa and Molí (1997) stated the maximum age of common two-banded seabream as 6 years which substantially differs from our study. The probable reason in this case could be the sampling method because they used spearfishing to capture the largest individuals. More important than the sampling gear, it is considered to be the size range sampled and the sample from this study presents sizes smaller than the ones found in the West Mediterranean and especially with the ones found in the Atlantic. However, phi-prime index values of all species are within the minimum and maximum values of the previous studies with no statistical significant difference.

Reproduction strategy of three of the sparids has been reported to be hermaphroditism while large-eye dentex is described as a gonochorist species (Bauchot and Hureau 1986). Potts et al. (2010) supported the gonochorism in large eye dentex as they did not observe any macroscopic evidence of hermaphroditism. Common two-banded seabream and axillary seabream were reported to be protandric species (Gonçalves and Erzini 2000, Velasco et al. 2011) while bogue is known as a diandric species (Monteiro et al. 2006).
The first reproduction age of the three species was determined to be 1 year but axillary seabream differs from the others as it was found to be 2 years. Our results are in harmony with those of Coelho et al. (2005) as they determined all immature axillary seabream specimens to be either age 0 or 1 . Similarly to the age findings, the greatest first reproduction size belongs to axillary sea bream for both males (13.9 cm TL) and females (14.5 cm TL). Length at first maturity of bogue was found as $L_{m}=13.0 \mathrm{~cm}$ for females (Fig. 6). On the other hand, length at first maturity for males couldn't be calculated due to insufficient data. The reason for this may be attributable to size range and size frequency of the males obtained. Monteiro et al. (2006) reported the minimum reproduction length of bogue as $15.2 \mathrm{~cm}$ total length and between 1-3 years for all individuals in Portugal. Furthermore Gordo (1995) stated the first reproduction length 13 and $14 \mathrm{~cm}$ for males and females respectively in the same area. Slight differences between our study and the mentioned studies above are considered to be grounded on regional discrepancies and size classes. Poor findings on the reproduction of large-eye dentex prevent making comprehensive discussions. In our study, first gonad formation occurred at 7.4 and $6.7 \mathrm{~cm}$ total length for females and males respectively. However, the length at which $50 \%$ of the individuals

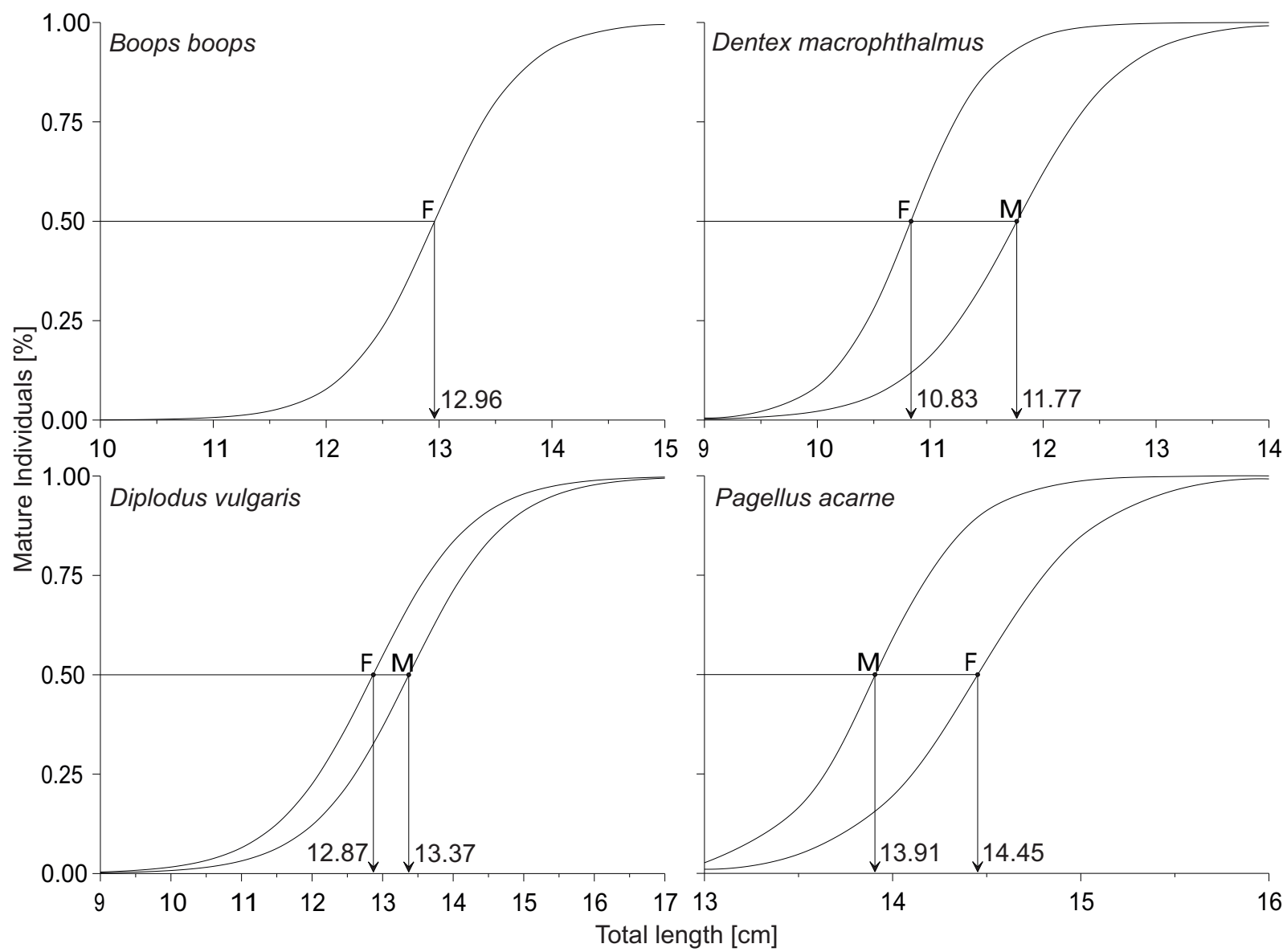

Fig. 6. First reproduction length according to sex for Boops boops, Dentex macrophthalmus, Diplodus vulgaris, and Pagellus acarne from east-central Aegean Sea, Turkey 
form gonads was found as $10.8 \mathrm{~cm}$ for females and 11.8 $\mathrm{cm}$ for males. Magnússon and Magnússon (1987) ${ }^{*}$ reported the first reproduction length as $19.3 \mathrm{~cm}$ total length in Cape Verde Islands. Potts et al. (2010) stated the lengthat-50\% maturity for all fish was $16.0 \mathrm{~cm}$ fork length (FL), with males maturing at a smaller size $(15.1 \mathrm{~cm} \mathrm{FL})$ than females $(16.6 \mathrm{~cm}$ FL). The differences between the results of our study and the studies listed above are attributable to regional discrepancies and sampling methods. Our findings on the first reproduction length and age of large-eye dentex present the first reliable results for the Aegean Sea. Fifty per cent maturity length of common two-banded seabream was determined to be $12.9 \mathrm{~cm}$ for females and $13.4 \mathrm{~cm}$ for males while length at $50 \%$ maturity were reported to be $17.27 \mathrm{~cm}$ for males and $17.65 \mathrm{~cm}$ for females by Gonçalves et al. (2003) from Algarve (Portugal). Similarly, Mouine et al. (2012) stated the length at maturity to be 17.1 and 17.6 for females and males respectively from Tunisia. The probable reason for these differences between our study and the others is considered to be the size range as the mentioned studies include bigger size classes (13.8-37.9 and 12.3-32.0 cm reported by Gonçalves et al. (2003) and Mouine et al. (2012), respectively). Nevertheless, axillary seabream, as a less studied species, primarily formed gonads at 12.5 ( $($ ) and $12.2(\widehat{\jmath}) \mathrm{cm}$ total length, while lengths at first maturity were found to be 14.5 and $13.9 \mathrm{~cm}$ for females and males, respectively. Velasco et al. (2011) stated that lengths at first maturity to be $18.04 \mathrm{~cm}$ for males and $21.7 \mathrm{~cm}$ for females from the Gulf of Cadiz, and $17.7 \mathrm{~cm}$ and $20.1 \mathrm{~cm}$ for males and females from the Alboran Sea, respectively. Coelho et al. (2005) reported the first maturity length for females as $17.6 \mathrm{~cm}$ and for males as $18.1 \mathrm{~cm}$ TL from Southern Portugal longline fishery. Differences could be more attributable to sampling gear and the size range than any other aspect. The results of our study present comprehensive information on the growth parameters and reproduction of common two-banded and axillary seabreams for Aegean Sea. It is obvious that the above-mentioned species in Aegean Sea (Mediterranean) mature at smaller sizes than the ones from the Atlantic. Stergiou et al. (1997) reported that the occurrence of short length (dwarfism) in benthic invertebrates inhabiting the eastern Mediterranean; Metin et al. (2011) also added that this situation may also be valid for fish species in the same region. Furthermore, it is known that the water temperature of Mediterranean is higher than the Atlantic. Metabolic activity rises with the increase in the water temperature which enables Mediterranean fish to perform reproductive activities at smaller sizes and younger than the ones found in Atlantic. In addition, fisheries may also affect this situation because fishing pressure is reducing the length at first reproduction therefore smaller individuals may be recruited to reproduce.

Mortality ratios of bogue, large-eye dentex, and axillary seabream were estimated and while the fishing mor- tality was over 1 for bogue and axillary seabream, it was less than 1 for large-eye dentex. Consequently, exploitation ratios of three of the species indicate high catch pressure decreasing from bogue $(0.874)$ to large-eye dentex $(0.540)$ with an intermediate value for axillary seabream (0.758). Monteiro et al. (2006) reported mortality parameters of bogue as $M=0.33, Z=1.04$, and $F=0.71$ with an exploitation rate of 0.68 . Mortality and exploitation ratios of common two-banded seabream couldn't be discussed due to insufficient number of specimens captured in the legal fishing zone. However, Gonçalves et al. (2003) reported the total mortality $(Z)$ and natural mortality $(M)$ of common two-banded seabream as 0.63 and 0.45 per year, respectively. They also stated the fishing mortality $(F)$ to be $0.18 \mathrm{y}^{-1}$ with an exploitation ratio of 0.28 per year which indicates a sustainable fishery for this species. As known so far, not only trawlers and purse seiners, but also artisanal and small scale fishing fleets have been targeting these valuable species for many years, especially in the Mediterranean. While bogue has been mostly captured by purse seiners, the rest are mainly caught by trammel nets and longlines (Kinacigil and İlkyaz 1997). The catch composition of Aegean Sea demersal trawl fishery includes all these species because of the multispecies character of Mediterranean fishery. Another important point is the role of recreational fisheries on these species which has not been measured yet and considered to create a high catch pressure in Turkey. Unfortunately it is impossible to determine the effects of each fishing gear on the catch amounts of these species due to official fishing statistics of Turkey and it is grounded on lack of data collection of catch per gear type.

The purpose of the presently reported study was to investigate the length distribution, length-weight relation, age, growth, spawning period, first maturity age, and length of four commercially exploited sparids (Boops boops, Dentex macrophthalmus, Diplodus vulgaris, and Pagellus acarne) in the central Aegean Sea. Although some studies have been conducted on the biology of these species, there are still some points which are scarce and variable especially for large-eye dentex, common twobanded and axillary seabream. Therefore, additional research is required in order to expand our knowledge of the biology, ecology and fisheries on these species for sustainable utilization.

\section{ACKNOWLEDGEMENTS}

The presently reported study was carried out with financial support from the Scientific and Technological Research Council of Turkey (TUBITAK) project 103 Y132 and the Ege University Science and Technology Center (EBILLTEM) project 2005/BİL/003. We would like to thank Marga McElroy for revising the English text.

\footnotetext{
* Magnússon J., Magnússon J.V.V. 1987. Survey of demersal fish resources in the waters off Cape Verde Islands. IV. Report: Summary of information on species. The Icelandic International Development Agency (ICEIDA) Marine Research Institute.
} 


\section{REFERENCES}

Abdallah M. 2002. Length-weight relationship of fishes caught by trawl off Alexandria, Egypt. Naga 25 (1): 19-20.

Abecasis D., Bentes L., Coelho R., Correia C., Lino P.G., Monteiro P., Gonçalves JMS., Ribeiro J., Erzini K. 2008. Ageing seabreams: A comparative study between scales and otoliths. Fisheries Research 89 (1): 37-48.

DOI: 10.1016/j.fishres.2007.08.013

Alegria-Hernandez V. 1989. Study on the age and growth of bogue (Boops boops (L.)) from the central Adriatic Sea. Cybium 13 (3): 281-288.

Anato C.B., Ktari M.H. 1986. Age et croissance de Boops boops (Linné, 1758) poisson téléostéen Sparidaé des côtes tunisiennes. Bulletin de l'Institut national scientifique et technique d'océanographie et de Pêche, Salammbô 13 (1): 33-54.

Anonymous 2012. Su Ürünleri İstatistikleri Fishery Statistics 2012. Yayın No Publication Number 4119. Türkiye İstatistik Kurumu Turkish Statistical Institute, Ankara, Turkey. [In Turkish and in English.]

Bauchot M.-L., Hureau J.-C. 1986. Sparidae. Pp 883-907. In: Whitehead P.J.P., Bauchot M.-L., Hureau J.-C., Nielsen J., Tortonese E. (eds.) Fishes of the north-eastern Atlantic and the Mediterranean. Vol. 2. UNESCO, Paris.

Beltrano A.M., Cannizzaro L., Vitale S., Milazzo A. 2003. Aspetti della bologia di Diplodus vulgaris (Pisces: Sparidae) nello stretto di Sicilia. [Biological aspects of Diplodus vulgaris (Pisces: Sparidae) in the Strait of Sicily.] Biologia Marina Mediterranea 10 (2): 287-290. [In Italian.]

Bradai M.N., Ghorbel M., Jarboui O., Bouain A. 1998. Croissance de trois espèces de sparidés : Diplodus puntazzo, Diplodus vulgaris et Spondylosoma cantharus du golfe de Gabès (Tunisie). Pp 51-56. In: Lleonart J. (ed.) Dynamique des populations marines. No: 35. CIHEAM, Zaragoza.

Cailliet G.M., Andrews A.H., Burton E.J., Watters D.L., Kline D.E., Ferry-Graham L.A. 2001. Age determination and validation studies of marine fishes: Do deep-dwellers live longer? Experimental Gerontology 36 (4-6): 739-764. DOI: $10.1016 / \mathrm{S} 0531-5565(00) 00239-4$

Campana S.E. 2001. Accuracy, precision and quality control in age determination, including a review of the use and abuse of age validation methods. Journal of Fish Biology 59 (2): 197-242. DOI: 10.1111/j.1095-8649.2001.tb00127.x

Campillo A. 1992. Les pêcheries françaises de Méditerranée: synthèse des connaissances Ifremer, France: http://archimer.ifremer.fr/doc/1992/rapport-1125.pdf

Casselman J.M. 1987. Determination of age and growth. Pp. 209-242. In: Weatherley A.H., Gill H.S. (eds.) The biology of fish growth. Academic Press, London.

Coelho R., Bentes L., Correia C., Gonçalves J.M.S., Lino P.G., Monteiro P., Ribeiro J., Erzini K. 2005. Age, growth and reproduction of the axillary seabream, Pagellus acarne (Risso, 1827), from the south coast of Portugal. Thalassas 21 (1): 79-84.

Cubillos L.A. 2003. An approach to estimate the natural mortality rate in fish stock. Naga 26 (1): 17-19.

Cicek E., Avsar D., Yeldan H., Ozutok M. 2006. Length-weight relationships for 31 teleost fishes caught by bottom trawl net in the Babadillimani Bight (northeastern Mediterranean). Journal of Applied Ichthyology 22 (4): 290-292.

DOI: $10.1111 / \mathrm{j} .1439-0426.2006 .00755 . \mathrm{x}$

Djabali F., Boudraa S., Bouhdid A., Bousbia H., Bouchelaghem E.H., Brahmi B., Dob M., Derdiche O., Djekrir F., Kadri L., Mammasse M., Stambouli A., Tehami B. 1990. Travaux réalisés sur les stocks pélagiques et démersaux de la région de Béni-saf. FAO Fisheries and Aquaculture Report 447: 160-165.

Djabali F., Mehailia A., Koudil M., Brahmi B. 1993. Empirical equations for the estimation of natural mortality in Mediterranean teleosts. Naga 16 (1): 35-37.

Dorel D. 1986. Poissons de l'Atlantique nord-est relations taillepoids. Ifremer, DRV-86-001/RH/NANTES.

Družinin A.D. [Druzhinin A.D.] 1976. Sparovye ryby Mirovogo okeana. [Sparid fishes of the world oceans.] Piŝevaja promyšlennost', Moskva, USSR.

Dulčić J., Kraljević M. 1996. Weight-length relationship for 40 fish species in the eastern Adriatic (Croatian waters). Fisheries Research 28 (3): 243-251.

DOI: 10.1016/0165-7836(96)00513-9

El-Haweet A., Hegazy M., AbuHatab H., Sabry E. 2005. Validation of length frequency analysis for Boops boops (bogue) growth estimation. Egyptian Journal of Aquatic Research 1 (1): 399-408.

Fehri-Bedoui R., Mokrani E., Ben Hassine O.K. 2009. Feeding habits of Pagellus acarne (Sparidae) in the Gulf of Tunis, central Mediterranean. Scientia Marina 73 (4): 667-678.

DOI: $10.3989 /$ scimar.2009.73n4667

Froese F., Pauly D. (eds.) 2014. FishBase. [version 02/2014] http://www.fishbase.org.

Gonçalves J.M.S., Bentes L., Coelho R., Correia C., Lino P.G., Monteiro C.C., Ribeiro J., Erzini K. 2003. Age and growth, maturity, mortality and yield-per-recruit for two banded bream (Diplodus vulgaris Geoffr.) from the south coast of Portugal. Fisheries Research 62 (3): 349-359. DOI: 10.1016/S0165-7836(02)00280-1

Gonçalves J.M.S., Bentes L., Lino P.G., Ribeiro J., Canário A.V.M., Erzini K. 1997. Weight-length relationships for selected fish species of the small-scale demersal fisheries of the south and south-west coast of Portugal. Fisheries Research 30 (3): 253-256. DOI: 10.1016/S0165-7836(96)00569-3

Gonçalves J.M.S., Erzini K. 2000. The reproductive biology of the two-banded sea bream (Diplodus vulgaris) from the southwest coast of Portugal. Journal of Applied Ichthyology 16 (3): $110-116$. DOI: $10.1046 / \mathrm{j} .1439-0426.2000 .00232 . \mathrm{x}$

Gordo, L.S. 1995. Gametogenesis in Boops boops (L., 1758). Boletim Do Instituto Português de Investigação Marítima 1: 79-91.

Gordoa A., Molí B. 1997. Age and growth of the sparids Diplodus vulgaris, D. sargus and D. annularis in adult populations and the differences in their juvenile growth patterns in the north-western Mediterranean Sea. Fisheries Research 33 (1-3): 123-129.

DOI: $10.1016 / \mathrm{S} 0165-7836(97) 00074-\mathrm{X}$

Gunderson D.R. 1993. Surveys of fisheries resources. John Wiley, New York, NY, USA. 
İlkyaz A.T, Metin C., Kınacıgil H.T. 1998. Örtü torba yöntemi ile örneklenen sürütme ağlarında seçicilik parametrelerinin hesaplanmas1 üzerine bir bilgisayar programı (L50 Sürüm:1.0.0). [A computer program about the calculation of the selectivity parameters in towed fishing gear illustrated with cover cod-end method (L50 Version 1.0.0).] Ege Üniversitesi Su Ürünleri Dergisi 15 (3-4): 305-314. [In Turkish.]

Ismen A., Ozen O., Altinagac U., Ozekinci U., Ayaz A. 2007. Weight-length relationships of 63 fish species in Saros Bay, Turkey. Journal of Applied Ichthyology 23 (6): 707-708. DOI: 10.1111/j.1439-0426.2007.00872.x

Karakulak F.S., Erk H., Bilgin B. 2006. Length-weight relationships for 47 coastal fish species from the northern Aegean Sea, Turkey. Journal of Applied Ichthyology 22 (4): 274-278. DOI: 10.1111/j.1439-0426.2006.00736.x

Khemiri S., Gaamour A., Zylberberg L., Meunier F., Romdhane M.S. 2005. Age and growth of bogue, Boops boops, in Tunisian waters. Acta Adriatica 46 (2): 159-175.

Kilongo K., Barros P., Diehdiou M. 2007. Diet of large-eye dentex Dentex macrophthalmus (Pisces: Sparidae) off Angola and Namibia. African Journal of Marine Science 29 (1): 49-54.

DOI: 10.2989/AJMS.2007.29.1.4.69

King M. 1996. Fisheries biology assessment and management. Fishing News Books, Farnham, England.

Kınacıgil H.T., İlkyaz A.T. 1997. Ege Denizi balıç̧1lı̆ı ve sorunlar1. [Sea fisheries in Aegean Sea.] Ege Üniveristesi Su Ürünleri Dergisi 14 (3-4): 351-367. [In Turkish.]

Mendes B., Fonseca P., Campos A. 2004. Weight-Length relationships for 46 fish species of the Portuguese west coast. Journal of Applied Ichthyology 20 (5): 355-361. DOI: $10.1111 / \mathrm{j} .1439-0426.2004 .00559 . \mathrm{x}$

Mennes F. 1985. Multispecies assessment of fish stocks off the Western Sahara region with emphasis on the family Sparidae. Fishbyte 3 (3): 5-10.

Merella P., Quetglas A., Alemany F., Carbonell A. 1997. Length-weight relationship of fishes and cephalopods from the Balearic Islands (Western Mediterranean). Naga 20 (3-4): 66-68.

Metin G., İlkyaz A.T., Soykan P., Kınacıgil H.T. 2011. Biological characteristics of the common pandora, Pagellus erythrinus (Linnaeus, 1758), in the central Aegean Sea. Turkish Journal of Zoology 35 (3): 307-315. DOI: 10.3906/zoo-0904-4

Monteiro P., Bentes L., Coelho R., Correia C., Gonçalves J.M.S., Lino P.G., Ribeiro J., Erzini K. 2006. Age and growth, mortality, reproduction and relative yield per recruit of the bogue, Boops boops Linné, 1758 (Sparidae), from the Algarve (south of Portugal) longline fishery. Journal of Applied Ichthyology 22 (5): 345-352. DOI: $10.1111 / \mathrm{j} .1439-0426.2006 .00756 . x$

Mouine N., Francour P., Ktari M.H., Chakroun-Marzouk N. 2012. Reproductive biology of four Diplodus species, Diplodus vulgaris, D. annularis, D. sargus sargus and D. puntazzo (Sparidae) in the Gulf of Tunis (central Mediterranean). Journal of the Marine Biological Association of the United Kingdom 92 (3): 623-631. DOI: $10.1017 /$ S0025315411000798
Moutopoulos D.K., Stergiou K.I. 2002. Length-weight and length-length relationships of fish species from the Aegean Sea (Greece). Journal of Applied Ichthyology 18 (3): 200-203. DOI: 10.1046/j.1439-0426.2002.00281.x

Nguyen X.L., Wojciechowski J. 1972. Comparative biology of fish from genus Dentex (Sparidae) of north-west African Coast. Acta Ichthyologica et Piscatoria 2 (2): 77-79.

Özaydın O., Uçkun D., Akalın S., Leblebici S., Tosunoğlu Z. 2007. Length-weight relationships of fishes captured from Izmir Bay, Central Aegean Sea. Journal of Applied Ichthyology 23 (6): 695-696. DOI: $10.1111 /$ j.1439-0426.2007.00853.x

Pajuelo J.G., Lorenzo J.M. 2000. Reproduction, age, growth and mortality of axillary seabream, Pagellus acarne (Sparidae), from the Canarian archipelago. Journal of Applied Ichthyology 16 (2): 41-47. DOI: 10.1046/j.1439-0426.2000.00154.x

Pajuelo J.G., Lorenzo J.M. 2003. The growth of the common two-banded seabream Diplodus vulgaris (Teleostei, Sparidae), in Canarian waters, estimated by reading otoliths and by backcalculation. Journal of Applied Ichthyology 19 (2): 79-83. DOI: 10.1046/j.1439-0426.2003.00359.x

Pauly D., Munro J.L. 1984. Once more on growth comparison in fish and invertebrates. Fishbyte 2 (1): 21.

Petrakis G., Stergiou K.I. 1995. Weight-length relationships for 33 fish species in Greek waters. Fisheries Research 21 (3-4): 465-469.

DOI: 10.1016/0165-7836(94)00294-7

Phâń L.T., Kompowski A. 1972. The bronze bream, Pagellus acarne Risso from the north west African region. Acta Ichthyologica et Piscatoria 2 (1): 1-18.

Potts W.M., Inácio L.A., Santos C.V., Richardson T.J., Sauer W.H. 2010. Aspects of the biology and fisheries of an economically important sparid Dentex macrophthalmus (Bloch 1791) in the Namibe province, Angola. African Journal of Marine Science 32 (3): 601-611. DOI: $10.2989 / 1814232 X .2010 .538160$

Ricker W.E. 1973. Linear regressions in fishery research. Journal of the Fisheries Research Board of Canada 30 (3): 409-434. DOI: 10.1139/f73-072

Ricker W.E. 1975. Computation and interpretation of biological statistics of fish populations. Bulletin of the Fisheries Research Board of Canada No. 191.

Sparre P., Venema S.C. 1998. Introduction to tropical fish stock assessment. Part 1: Manual. FAO Fisheries Technical Paper No. 306/1, Rev. 2. FAO, Rome.

Stergiou K.I., Moutopoulos D.K. 2001. A review of length-weight relationships of fishes from Greek marine waters. Naga 24 (1-2): 23-39.

Stergiou K.I., Christou E.D., Georgopoulous D., Zenetos A., Souvermezoglou C. 1997. The Hellenic seas: physics, chemistry, biology and fisheries. Pp. 415-538. In: Ansell A.D., Gibson R.N., Barnes M. (eds.) Oceanography and marine biology: an Annual Review. Aberdeen University Press, Aberdeen, Scotland.

Tosunoğlu Z., Akyol O., Metin G., Tokaç A., Ünsal S. 1997. Gülbahçe körfezi'ndeki üç sparid türünün populasyon özelliklerinin araştırılması. [The study on the population characteris- 
tics of three sparid species in the Gülbahçe Bay.] Ege Üniveristesi Su Ürünleri Dergisi 14 (1-2): 127-143. [In Turkish.]

Tosunoğlu Z., Kaykaç M.H., Aydın C., Tokaç A. 1996. E.Ü. Su Ürünleri Fakültesi balıkçılık araştırmalarında kullanılan dip trol ağları. [Bottom trawl nets used in fishery researches of Ege University, Faculty of Fisheries.] Ege Üniversitesi Su Ürünleri Dergisi 13 (3-4): 485-498. [In Turkish.]

Tsangridis A., Filippousis N. 1991. Use of length-frequency data in the estimation of growth parameters of three Mediterranean fish species: bogue (Boops boops L.), picarel (Spicara smaris L.) and horse mackerel (Trachurus trachurus L.). Fisheries Research 12 (4): 283-297.

DOI: 10.1016/0165-7836(91)90013-6

Valle C., Bayle J.T., Ramos A.A. 2003. Weight-length relationships for selected fish species of the western Mediterranean Sea. Journal of Applied Ichthyology 19 (4): 261-262. DOI: $10.1046 / j .1439-0426.2003 .00492 . x$
Velasco E.M., Jiménez-Tenorio N., Del Arbol J., Bruzón M.A., Baro J., Sobrino I. 2011. Age, growth and reproduction of the axillary seabream, Pagellus acarne, in the Atlantic and Mediterranean waters off southern Spain. Journal of the Marine Biological Association of the United Kingdom 91 (6): 1243-1253. DOI: $10.1017 / \mathrm{S} 0025315410000305$

Zoubi A. 2001. Etude de la biologie de croissance des principaux stocks démersaux de la Méditerranée marocaine. Rapport du Congrès de la Commission Internationale pour l'Exploration Scientifique de la Mer Méditerranée 36: 341-341.

Zúñiga L.R. 1967. Estudio del crecimiento de Boops boops (L.) del Levante. Investigación Pesquera 31 (3): 383-418.

Received: 16 July 2014

Accepted: 8 December 2014

Published electronically: 31 March 2015 